\title{
Methodology and Irony
}

As already mentioned, the characteristic, indeed defining or essential, feature of satire is a pervasive sense of irony. Accordingly, I begin this chapter with a general discussion of irony before providing a detailed outline of the most influential theory of irony, namely, that of Douglas Muecke. It is Muecke's theory and taxonomy of irony, which I have adjusted, that I apply to the SN for the purpose of establishing that the $\mathrm{SN}$ is in fact possessed of a pervasive sense of irony and, therefore, ought to be understood as satire. (Or, at least, the SN ought to be so understood, given the presence of certain other elements of satire-see section 1.2.1.2. above.) The following sections (2.1.1.-2.1.3.) delve into the nature of irony in general terms, particularly as it relates to satire.

\subsection{Irony}

\subsubsection{Etymology}

Irony can be detected in history before the phenomenon was called irony. ${ }^{1}$ However, the word irony originated in the Greek dramas which revolved around the characters of the alazōn and the eirōn. The alazōn was characterised as being full of pretence and ignorance, whereas the eirōn (who appeared to be ignorant) was actually the character with the greater insights who exposed the gaps in the alazōn's argument. The word irony is, therefore, derived from the Greek word eironeia (which is linked to the character of the eirōn), and is variously described as dissimulation, feigning ignorance, hiding under a false pretence, hypocrisy, and deception. ${ }^{2}$

\subsubsection{Function of Irony}

In its simplest form irony may be no more than a polite or witty expression. It would be a great stretch of the imagination to suggest that the comment "it's a great day today" on a miserable day is anything more than a light exchange about the weather. However, when irony is used in a sustained manner, the

1 Muecke, The Compass of Irony, 14.

2 Douglas Harper (2008-2011) http://www.etymonline.com/index.php?allowed_in_frame=o\&s earch=irony\&searchmode=none. 
function is to critique and reform society. Irony makes this change through the power of language. For example,

Language makes possible the accumulation and transmission of culture, embodying and shaping that culture in the very process of transmission. Similarly, the formation of identity is at once made possible and radically circumscribed by the structures of language as a primary vehicle of socialization ${ }^{3}$... irony in narrative creates a linguistic matrix in which the imagination can function, and, therefore also a medium with which the community can interact with its tradition, evaluating and shaping its contents, and appropriating them for new and different circumstances. ${ }^{4}$

In other words, the evolution of society comes about by working through conflicting discourse and not out of thin air; the old way of thinking always lives next to the new way of thinking, as they are dependent upon each other. For instance, Wayne Booth speaks of irony as a reconstruction. He sees irony as pulling down an old dwelling place whilst it builds another one, overlooking the old site. ${ }^{5}$ This process of rebuilding is always constructive as the higher purpose of irony is conceived of as just. For instance, historically, the higher purpose of irony was for Socrates a static sense of eternal love, ${ }^{6}$ for Rorty the absence of cruelty, ${ }^{7}$ and for Carolyn Sharp to get closer to God. ${ }^{8}$ Edwin Good has suggested that the presence of irony is a criterion for "liberating faith." Properly conducted ironic dialogue resolves the tension between two streams of thought in a way that is constructive for human beings and for society.

3 Jerry Camery-Hoggatt, Irony in Mark's Gospel (Cambridge: Cambridge University Press, 1992), 22.

4 Ibid., 33 .

5 Wayne C. Booth, A Rhetoric of Irony (Chicago: Chicago University Press, 1974), 36. From a scientific perspective, Hunt and Goleman suggest that active thought must be contingent on what has gone before as active thought relies on information which is stored in the long-term memory. Daniel Goleman, Vital Lies, Simple Truth: The Psychology of Self Deception (New York: Simon and Schuster, 1985), 55-90.

6 Plato 1963, 563 [211e], as cited in Colebrook, Irony, $3^{1}$

7 Rorty, Contingency, Irony, and Solidarity, xv.

8 Carolyn Sharp, Irony and Meaning in the Hebrew Bible (Indiana: Indiana University Press, 2009).

9 Edwin M. Good, Irony in the Old Testament (Sheffield: The Almond Press, 1981), 245. Original date 1965 . 


\subsubsection{Types of Irony}

Irony is a diverse and ever-changing phenomenon. Therefore, when we speak of irony in an academic sense it is important to be specific. It is generally agreed that there are two different categories of irony, and here I use Muecke's definitions of irony: observable irony and instrumental irony..$^{10}$ Observational irony involves a state of affairs that is seen to be ironic by the observer who is also the person being communicated to i.e. the reader or hearer. ${ }^{11}$ However, there is no evidence of an ironist who is behind the scenes and who has intentionally presented the events as ironic in order to pejoratively criticise some person, group, idea etc. Dramatic irony is a species of observable irony. However, unlike some forms of observable irony, dramatic irony is primarily the irony of the theatre and like dramatic forms.

General irony ${ }^{12}$ is another species of observable irony in that it presents ironic situations, however, in these cases the ironic content is universal in character and applies to all people. For instance, the irony of individual human beings apparently possessed of free will and a desire to lead meaningful lives finding themselves in a purposeless, deterministic universe. This kind of irony is typically philosophical or artistic. ${ }^{13}$ However, as with other forms of observable irony, in general irony there is no ironist seeking to make a pejorative criticism.

Instrumental irony, on the other hand, is characterised by the presence of an ironist being intentionally ironical. ${ }^{14}$ Verbal irony is the species of instrumental irony that is used in satire, and as such, is utilised in this book. Verbal irony is distinct because it contains an ironist who is being deliberately ironical, the presence of a specific object of ironic attack, and a corrective intent. It is intentional in as much as there is an object of attack. There is a corrective intent in as much as the object of attack is morally problematic yet potentially retrievable. If the object of attack is a person then the person is an object by virtue of having transgressed morally and yet the moral order can be restored,

10 Here I use the terms from Muecke's most recent work, Irony and the Ironic, (New York: Routledge, 2018), 22-23.

11 In describing observable irony, Muecke gives the example of a pickpocket who has his pocket picked while he is in the process of going about his business of picking pockets. Muecke, The Compass of Irony, 100.

12 Also spoken of as Ironies of Dilemma, Amiel's Law of Irony, Kierkegaard's World Irony, Cosmic Irony, and Romantic Irony. Muecke, The Compass of Irony, 120, 147, 159.

13 Ibid., 119-122.

14 Muecke, Irony and the Ironic, 22. 
at least potentially, by means of ironic discourse. As mentioned above this is the kind of irony that is found in satire. Frye speaks of irony that is found in satire as 'militant' irony. It is militant because it is confrontational and unrelenting. The purpose of this kind of irony is to make moral judgements and generate morally acceptable outcomes. The moral judgment of the ironist then becomes the standard against which the actions or features of the object of ironic attack are measured and found wanting. ${ }^{15}$

\section{2 $\quad$ Methodology}

\subsubsection{The Essential Elements in Irony According to Muecke}

Muecke claims that there are three essential elements in all types of irony. They are as follows: two different levels in the narrative, an opposition between the levels, and the presence of 'innocence.' Muecke calls the different levels the "lower level" and the "upper level." The lower level is explicit and thus known to all participants, including the victim of irony (if there is a victim of irony). By contrast, the upper level is only implicit and, as such, not necessarily known to all participants. The lower level comprises the situation of the victim of the irony (if there is a victim), or the ironist's dissimulation (if there is an ironist). The upper level, on the other hand, is the situation as it is implied by the ironist. ${ }^{16}$ Consider the example of a student who is bragging about his superior performance in an exam, not knowing that he has actually failed. The situation as it appears to the student comprises the lower level and, indeed, is known to all participants, namely, that he has sat the exam and that he is bragging about his performance. On the other hand, the upper level comprises the situation as it appears to the ironist and consists of the hubris of the student and the fact that the student has failed. The upper level does not need to be fully or unambiguously 'presented' by the ironist. It is sufficient if the ironist evokes the thought in the observer. It may be as simple as a hint that the ironist does not see the situation as it is presented in the lower level, e.g. as the student in our example sees it. At the upper level the ironist implies that the victim of the irony does not apprehend his or her situation completely, and that the ironist does not accept the situation as it is presented in the lower level as being correct or complete. At the upper level, therefore, the observer of the irony is aware that the contradiction that he or she perceives is not recognised

\footnotetext{
15 Frye, Anatomy of Criticism. Four Essays, 223.

16 Ibid., 19.
} 
by the victim of the irony. ${ }^{17}$ By discussing irony in terms of two different stratified levels, the upper level (the implicit level) and the lower level (the explicit level), Muecke is suggesting that the ironist and the observer at the upper level are superior to the victim of irony at the lower level. ${ }^{18}$

The second element which is essential to all irony is an opposition between the levels. The opposition Muecke speaks of need only be an incongruity, contradiction or an incompatibility. This is usually the opposition between the explicit and the implicit, between what is said and what is meant, and between what the victim thinks or does and what the observer knows and expects of the victim. ${ }^{19}$ However, it is important to note the incongruity must be understood in a wide sense that includes inappropriate or unexpected comments rather than merely in the narrow sense that limits it to contradictory statements or incompatible events. Only the definition in the wide sense can account for overstatements and understatements since these rely on incongruencies that are a matter of degree, such as exaggeration, rather than absolute contradictions.

I reiterate that there need not be an ironist, i.e. someone intending the irony. Consider, for example, a tiger running down a street in Melbourne shortly after someone had confidently asserted that there are no tigers in Melbourne. Here the irony arises from the two events (the assertion followed by the arrival of the tiger), or in other words, no-one intends the irony. This is not the case in verbal irony, however.

The third element is 'innocence'. Here we need to be careful. As we have just seen there may not be an ironist. However, if there is one then the ironist always pretends to be innocent with respect to the ironic content. On the other hand, if there is no ironist, as in our tiger example, then there must be a victim of irony in Muecke's sense of a person who is confidently unaware of the irony. Of course, there can be both an ironist and a victim of irony. Suppose in our above exam example that the examiner-knowing what the student does not yet know, namely, that he has failed the exam - says to the boastful student that his performance exceeded expectations. Here the examiner is the ironist and is feigning ignorance by pretending to endorse the student's high opinion of himself but is implicitly disparaging the student. The student is the unknowing victim since he is confidently unaware of the irony. The content of the irony arises from the opposition between the student's boasts and the

\begin{tabular}{ll}
\hline 17 & Ibid. \\
18 & Ibid. \\
19 & Ibid., 29.
\end{tabular}


reality of his failure. Here I note that the victim may be possessed of confident ignorance without necessarily being boastful. ${ }^{20}$

At this point I diverge somewhat from Muecke's account. Firstly, there is a need to distinguish, as Muecke does not always do, between the feigned ignorance of the ironist (e.g. the examiner in the above exam scenario) and the actual ignorance of the victim (e.g. the student). Hence, contrary to what Muecke says, in sarcasm and overt irony the ironist feigns innocence, albeit there is typically no victim of irony since the person who is the object of the disparaging remarks is immediately aware of this. ${ }^{21}$ This brings me to a second point of divergence with Muecke. There is a need to distinguish, as Muecke does not always do, between the victim of irony-in the sense of the person who is confidently unaware of the irony - and the object of ironic attack. ${ }^{22} \mathrm{Of}$ course, in many instances of irony there is no object of ironic attack. However, in the category of irony of most interest to me, namely, verbal irony (see below) there is always an object of ironic attack. The object of ironic attack is always someone or something that is the object of pejorative criticism. In the above exam scenario, it is the boastful student. In the case of sarcasm it is the person about whom the disparaging remark is made. Notice that the victim of irony is not necessarily the object of ironic attack. In our exam scenario, the student is both the object of ironic attack and the unknowing victim. But suppose the boastful student's mother is present when the examiner says that his performance exceeded expectations and she suggests that a celebration is in order for her brilliant child. The mother is a victim since she has entirely missed the irony of the examiner's remark because she is understandably preoccupied with her son and his supposed achievement; but she is not the object of the examiner's disparaging attack.

All of the examples of verbal irony spoken of in this book are examples of simple irony. Simple irony is characterised by a conflict between the two levels. ${ }^{23}$

\subsubsection{The Elements of Verbal Irony}

Thus far the discussion on irony has focused on the three elements which Muecke suggests are essential to all types of irony. The following discussion will concentrate on the elements characteristic of verbal irony-the irony to be found in satire. Muecke suggests that verbal irony is characterised by the

\begin{tabular}{ll}
\hline 20 & Ibid., 29. \\
21 & Ibid., 20. \\
22 & Ibid., 34-39. \\
23 & Ibid., 20
\end{tabular}


presence of an ironist who is intentionally being ironical. This is in contrast to observable irony where it is "a condition of affairs" or "outcome of events." Here we need to keep in mind the threefold distinction made above between the feigned innocence of the ironist, the object of ironic attack and the unknowing victim of irony. As mentioned above, Muecke conflates the object of attack with the unknowing victim. Nevertheless, consistent with what Muecke says, the object of ironic attack can be something general and impersonal, such as an entire philosophical system, or it may be personal and specific, such as a particular person, e.g. David. ${ }^{24}$ On the other hand, victims of irony are always persons, i.e. beings capable of knowing.

Let me stress at the outset that, as Muecke points out, verbal irony always involves an ironist, an intended irony and an object of ironic attack-someone or something that is pejoratively criticised. Moreover, the ironist not only intends the irony but also intends the attack. Further, the ironist always engages in feigned innocence. However, there is not always an unknowing victim of irony, although there frequently is. In the $\mathrm{SN}$, for example, David is sometimes the object of ironic attack without being the unknowing victim of the irony.

As just mentioned, verbal irony always involves an ironist who intends the irony, however the ironist is not necessarily a character in the narrative. The ironist can also be a narrator (whether understood as the author or not) or, indeed, the author him/herself qua author. Moreover, in the case of impersonal irony the author as ironist communicates the irony via the characters and events. So, the persona of the author is manifest in the speech and actions of the characters and/or in the presentation of events. Thus, as Muecke points out, an inherently humorous event might be narrated by the author in a grave and detached tone.

Verbal irony is used in satire in order to challenge a point of view or expose folly, hypocrisy or vanity. ${ }^{25}$ However, as already mentioned, verbal irony can involve a direct opposition between what is said and what is meant, or the intended meaning may present as a subtle suspicion that everything is not what it seems. Given these differences, verbal irony is divided into different grades depending on how apparent the irony is. The three grades of irony which Muecke speaks of are: Overt, Covert, and Private Irony. ${ }^{26}$

$\begin{array}{ll}24 & \text { Ibid., 34. } \\ 25 & \text { Ibid., 232. } \\ 26 & \text { Ibid., 53. }\end{array}$


(1) Overt irony is immediately apparent, and is not ambiguous. ${ }^{27}$

(2) Covert irony is ambiguous and needs to be uncovered. ${ }^{28}$ Most of the irony in the $\mathrm{SN}$ is of this grade. An awareness that the author's opinion or line of argument contradicts the context within which the opinion or line of argument is presented suggests covert irony. Covert irony can be found in the 'whole' context in the following ways:

(a) "What we already know about the writer and the subject."

(b) "What the writer tells us about himself and the subject over and above his pretended meaning."

(c) "What we are told by the way in which he expresses his opinion, presents his case, or conducts his argument. That is to say, what is ostensibly said may be contradicted or qualified by:"

$1 \quad$ "Our prior knowledge as to,"

(a) "It's truth eg. 'Hitler was kind to Jews,' and/or,"

(b) “The author's real opinion, eg. 'God is good,' said by an atheist, and / or,"

(c) "The author's real character, if he presents himself as other than he is,"

and additionally, or alternatively by:

2 "What the author says or implies over and above what he seems to be saying. This internal contradiction may be,

(a) "A contradiction of facts or opinions,"

(b) "A logical contradiction"

(c) "A discordant tone in speaking or,"

(d) "Any discrepancy between what is said and the language in which it is expressed, eg. unsuitable metaphor or choice of words, or"29

(e) "Any discrepancy between what is ostensibly said and what is revealed of the author's real character"30

(3) Private irony, (which will not be discussed in this dissertation) is irony which is known only to the ironist. ${ }^{31}$

\begin{tabular}{ll}
\hline 27 & Ibid., 55. \\
28 & Ibid., 57. \\
29 & Ibid., 58. \\
30 & Ibid., 59. \\
31 & Ibid., 59.
\end{tabular}




\subsubsection{Diagram of Verbal Irony}

\section{VERBAL IRONY}

\section{UPPER LEVEL}

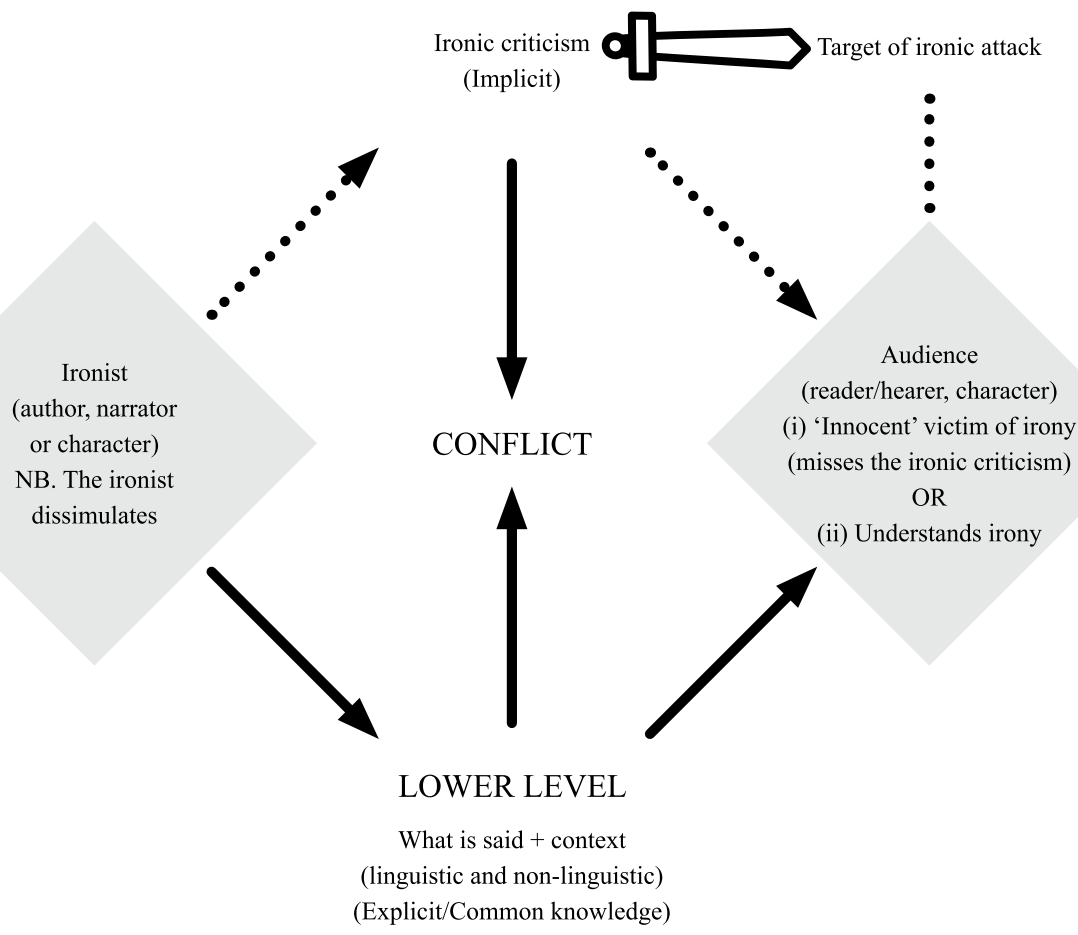

In addition to the three grades of irony, discussed above, Muecke argues for four modes of irony. The four modes concern the different possible presentations of the ironist. The four modes are outlined in section 2.2.4. 


\subsubsection{Table of the Four Modes of Verbal Irony ${ }^{32}$}

(1) IMPERSONAL IRONY -THE IRONIST IS EITHER AUTHOR, NARRATOR, OR CHARACTER Impersonal irony is irony which does not have a particular character in the narrative who is the ironist, as Socrates is in Plato's plays. Instead, in cases of Impersonal Irony the reader is aware of an ironist within the text as an authorial 'persona.'

\section{SUB-CATEGORIES OF IMPERSONAL IRONY ARE AS FOLLOWS:}

(1) Praising in Order to Blame-Including; praise for qualities known to be lacking, praise for having undesirable qualities or for lacking desirable qualities, or inappropriate or irrelevant praise.

(2) Blaming in Order to Praise-Including blame for undesirable qualities known to be lacking, blame for having desirable qualities or for lacking undesirable qualities, or inappropriate or irrelevant blame.

(3) Pretended Agreement with the Victim

(4) Pretended Advice or Encouragement to the Victim

(5) The Rhetorical Question

(6) Pretended Doubt

(7) Pretended Error or Ignorance

(8) Innuendo or Insinuation

(9) Irony by Analogy

(10) Ambiguity

(11) Pretended Omission of Censure

(12) Pretended Attack upon the Victim's Opponent

(13) Pretended Defence of the Victim

(14) Misrepresentation, or False Statement

(15) Internal Contradiction

(16) Fallacious Reasoning

(17) Stylistically Signally Irony_-Including; the ironical manner, stylistic placing, parody, mock-heroic, burlesque and travesty.

(18) Understatement

(19) Overstatement

(20) Irony Displayed-This is similar to Observable Irony; however, it can be distinguished by the identification of the ironist being ironical, or critical in the arrangement of events

(2) SELF-DISPARAGING IRONY

(3) INGÉNUE IRONY-THE PRESENCE OF A TRUE INNOCENT

(4) DRAMATIZED IRONY - EVENTS ARE DELIBERATELY ARRANGED TO BRING OUT THE IRONY

\subsubsection{Notes Regarding the Four Modes of Irony}

"Self-Disparaging Irony" can be detected when the ironist is present in the narrative as a person. ${ }^{33}$ This type of irony does not present in the SN. Ingénue irony presents when a true innocent is apparent, instead of a person who is

$\begin{array}{ll}32 & \text { Ibid., } 55^{-92 .} \\ 33 & \text { Ibid., } 87 .\end{array}$


dissimulating. ${ }^{34}$ In this type of irony the ironist withdraws further, and instead of feigning innocence uses a true innocent or an ingenui to expose the truth. ${ }^{35}$ The child in the story of the emperor's new clothes is a good example of a true innocent.

Of special note are the similarities between "Irony Displayed" and "Dramatized Irony." Both of these types of irony use events that are deliberately arranged to bring out the irony. The difference, as mentioned by Muecke, is that the ironist in Irony Displayed feigns detachment, and is motivated by contempt. Whereas, the ironist in Dramatized Irony really is detached and does not pretend to be earnest while he or she is being contemptuous. Instead, the ironist accepts the irony for what it is, and is less outraged than the ironist in Irony Displayed. For instance, "But we are more likely to find an Impersonal Ironist using irony to satirize, say, vanity, hypocrisy, and rationalizing, and more likely to find a Dramatizing Ironist looking upon manifestations of vanity, hypocrisy, and rationalizing as being in themselves instances of irony and content simply to present them as such." ${ }^{36}$ This mode of irony does not present in the SN.

Also of note, in concluding this section it is necessary to mention that Muecke is certain that his list is incomplete and that every instance of irony presents in a unique manner which requires flexibility in interpretation. ${ }^{37}$

\subsection{Verbal Irony and the Succession Narrative}

In this book I apply Muecke's generic definition of irony, and the specific grades, modes, and sub-categories of verbal irony to a sequential reading of the final form of the SN. The dominant grade of irony in the SN is covert. I do not mention private irony, since discerning this grade of irony presupposes an extent of knowledge of the author not available in the case of SN. The dominant mode of irony in the $\mathrm{SN}$ is impersonal irony since in the $\mathrm{SN}$ there is not a distinct character who is a consistent ironical personality throughout the text. There is evidence in the $\mathrm{SN}$ of most of the sub-categories of impersonal irony. In cases of overlapping sub-categories of irony, instances of the dominant sub-category of irony are used to justify my claim that verbal irony is present.

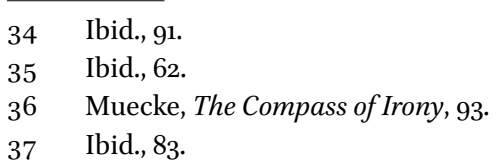

